\title{
DYNAMIC INTERRELATIONSHIP BETWEEN LANDFORM EVOLUTIONS, HUMAN HABITATION AND BIODIVERSITY IN GUNUNG SEWU KARST, JAVA-INDONESIA
}

\author{
Eko Haryono $^{1)}$, Jarwo Susetyo Edy Yuwono ${ }^{2)}$, Lies Rahayu Wijayanti Faida ${ }^{3)}$ \\ ${ }^{1)}$ Dept of Geography and Environmental Science, Fac. of Geography, Gadjah Mada University, e.haryono@ ugm.ac.id \\ ${ }^{2)}$ Dept of Archaeology, Fac. of Cultural Science, Gadjah Mada University, setyoedy@ yahoo.com \\ ${ }^{3)}$ Dept of Forest Conservation, Fac. of Forestry, Gadjah Mada University
}

\begin{abstract}
Gunung Sewu Karst is situated in the faulted block of Southern Java Zone, Indonesia. The area has been uplifted since the Late Pliocene. Three major uplift phases were reported to have been taking place, resulting in the exposure of Miocene carbonate rocks. Prevailing tropical monsoon climate has made it possible for the carbonate formations to evolve through karstification process. Three phases of the uplifting thereafter have resulted in three karst landform evolution. Karst landform evolution in Gunung Sewu Karst inevitably determined pre-historic human habitation. During the first stage when surface river was active, human settlement occupied open space along river courses. When the caves were exposed in the second stage, human settlement moved to the caves and distributed along dry valleys or near doline ponds. Cave habitations ended when major depression dried out provisions of extensive agricultural land. In the modern era, the situation was inverted in which the human habitation was determined by geomorphologic processes. Soil erosion was accelerated due to deforestation and agricultural land intensifications. Native species were replaced by exotic species commodities. Big mammals mentioned above were extinct.
\end{abstract}

Kewords : Gunung Sewu Karst, human habitation

\section{A. The Gunung Sewu Karst area}

Gunung Sewu Karst is situated in the faulted block of Southern Java Zone, which extends some $85 \mathrm{~km}$ east-west and slopes gently, at approximately a $2 \%$ gradient, southward, being marked by a high (25-100 m) cliff along the south coast (Pannekoek, 1949, Bemmelen, 1970). The Gunung Sewu area is adjacent to the Indian Ocean on the south central coast of Java. The elevation range is between zero and $400 \mathrm{~m}$ above mean sea level, in which its highest portions are centrally located about $25 \mathrm{~km}$ from the coastline (Figure 1).

Geologically, the study area is dominated by Miocene limestone of the Wonosari Formation, which consists of massive coral reef limestone in the south and bedded chalky limestone in the north (Balazs 1968; van Bemmelen 1970; Waltham et al. 1983; Surono et al. 1992). The total thickness exceeds $650 \mathrm{~m}$, and the limestone is underlain by volcanic and clastic rocks (Waltham et al. 1983). The coral reef limestone is lithologically highly variable but dominated by rudstones, packstones, and framestones. Breccias with a clay matrix are not uncommon, biohermal structures are identifiable, and lenses of volcanic ash are interspersed among the carbonates (Waltham et al. 1983). The bedded, chalky limestone becomes more prominent towards the north and northeast and dominates the Wonosari Plateau. The area has been uplifted since the Late Pliocene. Three major uplift phases were reported to have been taking place, resulting in the exposure of Miocene carbonate rocks (Bemmelen, 1977; Asikin, 1992; Surono et al., 1992; Samodra and Wiryosujono, 1993; Urushibara and Yosino, 1997). 


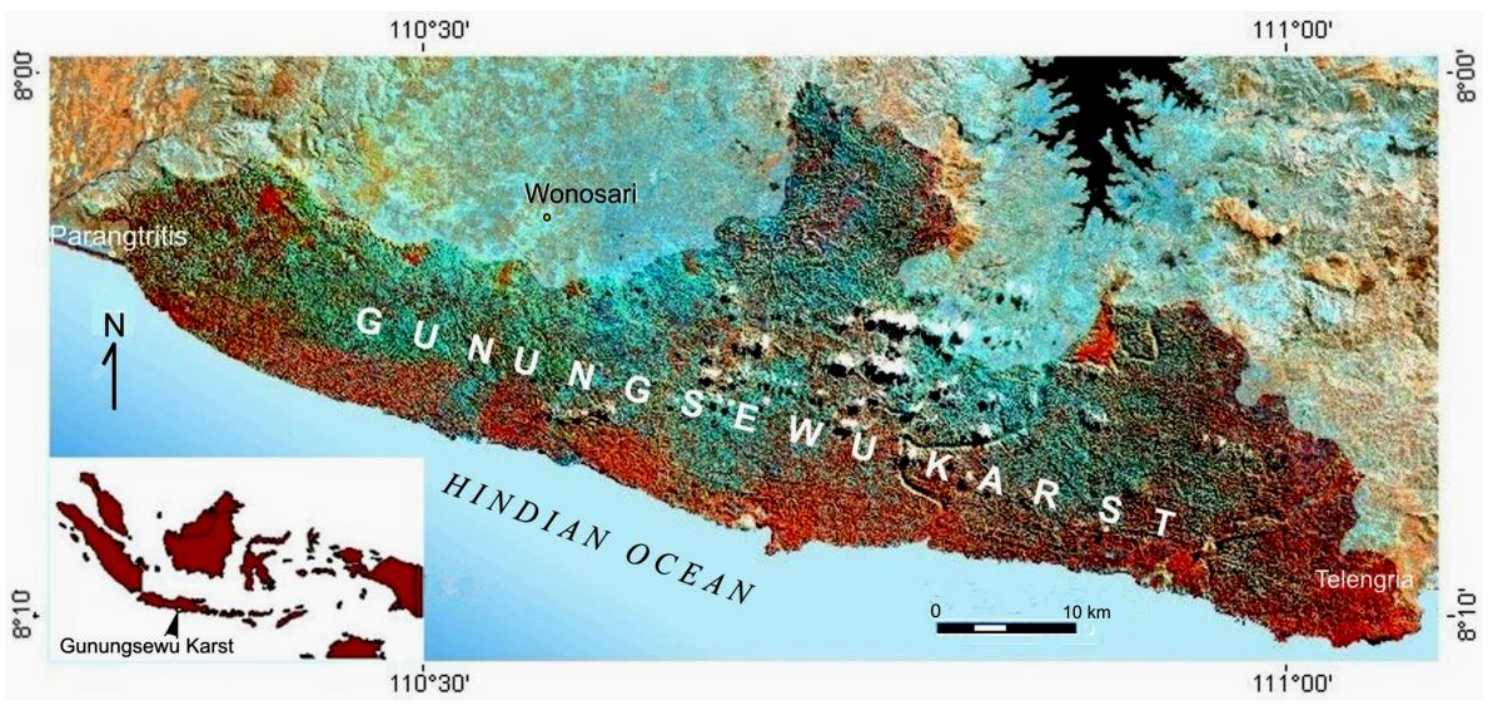

Figure 1. Landsat ETM depicting Gunung Sewu Karst and the surrounding areas

The prevailing contemporary climate in the Gunung Kidul is strongly influenced by the Northwest and Southeast monsoons, which produce a distinct wet season from October to April and a dry season, which may be extremely arid, between May and September. The annual rainfall is about $2000 \mathrm{~mm}$; records from 14 local rain gauge stations between 1960 and 1997 vary between $1500 \mathrm{~mm}$ and $2986 \mathrm{~mm}$ annually. An earlier mean annual rainfall, based on 33 years of record was quoted as $1809 \mathrm{~mm}$ and mean annual temperature is about $27^{\circ} \mathrm{C}$ (Haryono, 2001; Haryono and Day 2004).

\section{B. Landform evolution of Gunung Sewu Karst}

\section{First stage (Karst Inception)}

During the stage (Late Pliocene and Early Pleistocene), carbonate of Wonosari Fm slightly emerged to the surface. Karstification started, surface rivers developed, and lakes were formed in the major depression of the northern vicinity of Gunung Sewu Karst. Landform development is characterized by existence of low order valleys which are organized within open basin, parallel drainage pattern, and elongated basin form (Haryono, 2008).

Karst valley develops through carbonate dissolution along fracture structure by surface runoff. During this stage, surface rivers are active, even some of them are perennial rivers. Active surface rivers dissolve limestone in the base of river bank, forming shallow caverns. These caverns weaken slope stability and eventually trigger mass movement (mostly rockfall). Rockfall along riversides is also controlled by rock jointing. This process is the reason for the formation of vertical riverbank morphology found in the undeveloped karst such as in Rengel Karst. Dissolution and rock fall, therefore, are the main processes during inception stage (Haryono, 2008). 


\section{Second stage (Young Karst)}

In the second phase (Middle Pleistocene), the carbonate outcrop was uplifted and more extensive; incision along surface valley continued, resulting in deep valley and cave exposure. Young karst is characterized by high order valleys organized by open basin, dendritic drainage pattern or dendritic-parallel, low main valley gradient, and wide basin area with various plan forms. High order areas increase by $2.7-3$ folds compared to the lower order. In other words, the valley networks of young karst are similar to generally non karst areas. Young karst in the study areas is closely described as fluviokarst (Haryono, 2008).

Valley development in the second stage takes place when surface river dries out due to developed cavities in the valley bottom and the subsurface. Dissolution in the river bank stops and mass movements take place only in the upper part of dried valley. Rockfall boulders are getting smaller and deposited as scree fan in the valley base. This sediment, therefore, modifies valley cross section from $\mathrm{U}$ shape to blunt $\mathrm{V}$ shape (Haryono, 2008).

\section{Third stage (Mature Karst)}

The drastic change took place during the third stage (Late Pleistocene and Holocene) when Gunung Sewu Karst was completely exposed, reaching the maximum altitude of $500 \mathrm{~m}$ from MSL; most surface rivers dried out due to underground conduit development. Major lake was also drained through newly developed underground river system. Instead, pounds were scatterly formed in the bottom of dolines in which the ponor was plugged by sediment (Haryono, 2008).

The third stage is characterized by low order valley which is organized in closed depression, multi-basinal drainage pattern, small basin area, rounded plane basin shape, and high valley gradient. Karst in this stage has characteristic of polygonal karst. The third stage of valley development takes place when karst valleys become closed space. Fluvial process and mass movement are not active anymore. Cavities and secondary porosity are intensively developed. The main process is dissolution, occurring both in surface and subsurface. The dissolution process brings about valley profile smoothing, forming a half ball profile and conical hills. Mass movement depositing in the valley base is also dissolved and replaced by soil deposited from upper slope soil erosion (Haryono, 2008).

\section{Human habitation and biodiversity}

Karst landform evolution in Gunung Sewu Karst inevitably determined prehistoric human habitation. Gunung Sewu Karst has been experiencing long history of settlements. In the first stage of karst landform development, human habitation was in 
open site along surface riversides. Koningwald and Tweedie (1935) found very dense scatters of lithic artifacts along Baksoko River. The implements are generally made of pink (reddish) dark brown, blackish silicified tuff, opaque white silicified limestone, and some fossil wood. There are also massive tools still attached to conglomerate boulders on the slopes of the riverbank about 3-4 meters from the bottom of the river (Simanjutak, 2002). In additions to tools, Koningwald and Twedee found the existence of Ursus sp, Tapirus sp, Stegodon, Simia, Elephas namadicus, Echinosore, Symphalangus, and Hylobates.

The artifacts found in the Baksoko River were then named as Pacitanian Culture, derived from the word "Pacitan", the name of the nearest town of the area. Pacitanian culture was said to be Middle Pleistocene. This age is confirmed by recent finding of Semah and Semah in 1999 that succeeded in obtaining habitation chronology, covering from 180,000 to 4,500 in Terus Cave. This finding suggests that Pacitanian Culture is older than 180.000. Choppers represent the highest percentage of the massive tools, in addition to flake tools. The flat-iron and horse hoof types are characteristics of the Pacitan Culture. Von Koningwald concluded that the tool found from the area had characteristic attributes of Chellean hand-axes. The creator of Pacitanian Culture, however, is still unclear. No tools found in the area were associated with hominid fossils.

During the late Pleistocene (40,000 until 12,000), there was some change of cultural phenomenon. During this period, habitations moved to caves or rock shelters from those previously found along the river sides. This change had a great impact on cultural development. Life in temporary camps which had previously tended to be nomadic changed to more settled life in cave. This condition facilitated opportunities for innovations. Some typical characteristics of the late Pleistocene are 1) exploitation of caves and rock shelters for habitation and other activities, 2) exploitation of various kinds of rocks for tools, 3) subsistence by hunting, and 4) hominid culture bearers belonging to the species of Homo sapiens (Simanjutak, 2002).

Numerous lithic artifacts of waste flakes and flacking tools in the cave indicate that caves also serve as workshop for lithic tool making. However, lithic technology was not developed during this period, inferring from rarity of remains compared to waste flacks. The quantity of artifacts gradually decreased in deeper levels. The lithic artifacts tend to be denser in the upper layers, indicating that the lithic industry was developed rapidly near the Pleistocene-Holocene transition. Beside lithic tools, the cave dwellers had started to make implements from animal bones, although not as intensive as in the Holocene. The main source of subsistence during the late Pleistocene was hunting of game in the surrounding areas of the caves (Simanjutak, 2002; Yuwono, 2004).

Lithic industry reached their peak in the first half of Holocene. The product of lithic industry consisted of Palaeolithic, Pre-neolithic, and Neolithic. Paleolithic tools are 
core tools from limestone as chopping tools and choppers. Pre-neolithic traits were represented by flakes and blades, whereas Neolithic traits were represented by quadrangular adzes of limestone, mollusk shell, and bone fossils. Flake tools are the most common industry of Gunung Sewu Karst. Beside lithic industry, a bone industry was very well developed in Gunung Sewu karst, especially during Early Holocene. Bone tools in the area are classified as spatulas, points, needles, and tools made of antler (Simanjutak, 2002; Sutikno and Tanudirdjo, 2007; Yuwono, 2004).

The Neolithic of Gunung Sewu karst displayed unique characteristics with regards to its geographical orientation, technological aspect, and chronology. In the beginning, Neolithic technology was still cantered in caves and shelters, representing continuation of the Preneolithic culture. Subsequently, Neolithic sites shifted to open sites on plains and hill slopes. The shift from cave to open sites apparently was related to technological development. The plains and hill slope where cert. was easy to get for adze manufacturing, were selected as locations for settlements and workshops, rather than caves. Advancements in technology made it possible to exploit trees to build simple houses around the workshop. Neolithic culture is presumed to start from 4,000 BP up to 2,000 BP (Simanjutak, 2002; Sutikno and Tanudirdjo, 2007; Yuwono, 2004).

The prehistoric time of Gunung Sewu Karst was ended in Paleometalic Era. In this era, pottery making became more advanced, characterized by the use of paddle and anvil, combined with the use of potter's wheel and polishing technology. The time span covered by Palaeomethalic culture was shorter than that of Neolithic. This culture still existed 700 years ago. This culture did not last long, as evidenced by the thinness of the cultural layer in the excavation site (Simanjutak, 2002).

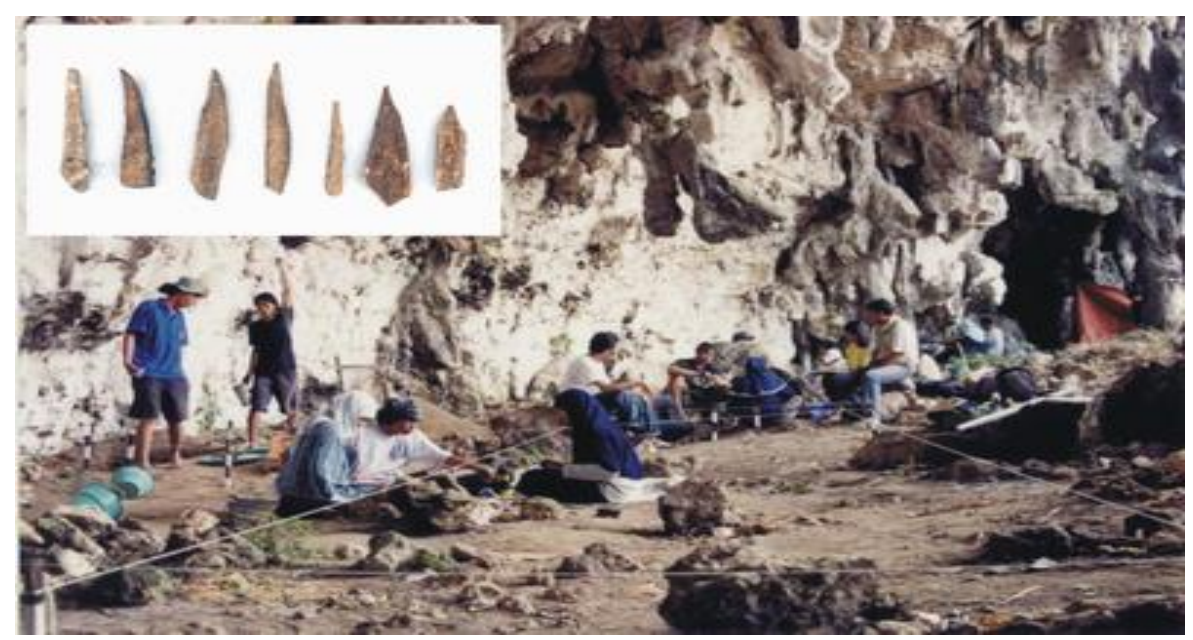

Figure 12. Typical of sheltered cave interior in Gunung Sewu Karst. Inset is points from early Holocene industry From: Yuwono, 2004 with the courtesy of PTKA UGM 
Gunung Sewu prehistoric time culture was prolonged. When the lowland areas and volcanic areas experienced Hindus culture, Gunung Sewu Karst still carried on prehistoric culture until better access was opened from the lowland surrounding areas. Hindus culture in Java island has started since the $4^{\text {th }}$ century, compared to that in Gunung Sewu Karst where no inscriptions were found (Yuwono, 2005, oral communication). As stated before, during the $4^{\text {th }}$ century, Gunung Sewu Karst was still undergoing Paleometalic Era.

Currently, Gunung Sewu Karst is inhabited by approximately 1,113,200 people scattering throughout the areas. No certain concentration of settlements is found. Population density varies from 281 to 452 people/ $\mathrm{km}^{2}$ (Table 1). Population growth rate is very low, lower than any other surrounding areas. The major livelihood of the people is still subsistence agriculture. As mentioned earlier, extensive cultivation is applied, reaching to the tops of karst hills. Every single plot of land is cultivated. Therefore, population pressure in the areas is higher than the agricultural carrying capacity as it is indicated by population pressure index that is higher than one (Table 7). Index of 3.41, for example, indicates that there must be 3.41 times more land than that of the existing agricultural land. Present traditions in the Gunung Sewu Karst are closely associated with agriculture culture. One of the important traditions is people festivity, the so-called Rasulan, that is held annually after harvesting time.

Table 1. Population of Gunung Sewu Karst

\begin{tabular}{|l|c|c|c|}
\hline \multicolumn{1}{|c|}{ District } & $\begin{array}{c}\text { Density } \\
\left(\text { people/km }{ }^{2}\right)\end{array}$ & $\begin{array}{c}\text { Growth rate } \\
(\% / \text { year })\end{array}$ & $\begin{array}{c}\text { Population } \\
\text { Pressure }\end{array}$ \\
\hline Purwosari & 281 & 0.001 & 1.51 \\
\hline Panggang & 282 & 0.002 & 2.04 \\
\hline Saptosari & 452 & 0.003 & 3.41 \\
\hline Tanjungsari & 385 & 0.002 & 2.85 \\
\hline Tepus & 367 & 0.003 & 2.57 \\
\hline Girisubo & 300 & 0.004 & 2 \\
\hline Rongkop & 371 & 0.003 & 2.67 \\
\hline Paranggupito & 345 & 0.002 & 3.1 \\
\hline
\end{tabular}

From: Anonymous (2001) and Anonymous (2003)

In addition to agriculture, fishery culture has been emerging since the last two decades, especially in the areas near costal zone. Inadequate agricultural production, farmers try to get alternative income from fishing in the Hindian Ocean. In accordance with this new livelihood, sea food restaurants serving fresh fishes are blooming in almost all beach tourist resorts. It seems that sea fishing will develop comparably fast in the near future. Local government has also been developing fishery sector through building several new harbours in the next five years along the coastline of Gunung Sewu Karst. 


\section{Biodiversity}

Gunung Sewu Karst has been subjected to deforestation since the late $19^{\text {th }}$ century. Since then, biodiversity is less abundant, compared to that before late $19^{\text {th }}$ century, when the area was still a primary forest. Deforestation has resulted in severe land degradation and extensive bare land. However, many species of animal and plant groups are still found in the area. Based on the identification of larger flora and fauna in the $20 \%$ area in the center part of Gunung Sewu Karst by Matala Biogama (2002) 66 species of plants, 32 species of aves, 18 species of mammal, and 23 species of reptile and amphibian were found.

Among the flora listed, almost all of the floras in Gunung Sewu Karst are cultivated crops. Some of those crops like Tectona grandis (teak), Cocos nucifera (Coconut), Parkia speciosa, Musa paradisiaca (Banana), Acacia auriculiformis (Acacia), Gnetum gnemon, Albizzia falcata, and Anacardium officidental, are the major commodity crops that are planted in mix garden. Whereas Zea mays (maize), Oryza spp. (rice), Manihot utilisima (Cassava), and Arachis hipogaea (ground nut) are planted in the dry field.

Domestic faunas that are economically important for people of Gunung Sewu Karst are cows (Bos indicus), lambs (Capra capra), and chickens. Almost all of families living in the karst area have at least a couple of cattle (two cows or lambs) and more than five chickens. Together with mentioned floras, these cattle constitute the major farming system employed. The faeces of cattle is utilized for organic fertilizer, in vice versa, some crops are used to feed the cattle. Economically, cattle are considered as saving by farmers that are usually sold to pay accidental expenses.

Wild fauna that has economical value in Gunungsewu karst are swiftlets (Apodidae Family). The colonies of swiftlets are found mostly in cliff cave facing to the Hindian Ocean. Two species of Aerodramus maxima and Aerodramus fuciphaga were found in the area (Noerdjito, 2000). Local people harvest the swiftlet nests by descending the cliff with traditional equipments. Cave flora and fauna of Gunungsewu karst have not been much explored yet. Arthropods as usually being the biggest faunal dwellers of caves have not also been described thoroughly. Rohmadi (2004) suggested that 11 species of triglobit and stigobit have been found in Gunungsewu Karst, but only four have been described. Those species among others are Sesarmoides jacobsoni, Parathelphusa convexa, Macrobrachium poeti, Macrobrachium pilimanus, Javanoscia elongata, Tenebrioscia antennuata, Sesarmoides jacobsoni, Javanoscia elongata, and Tenebroscia antennuata. 


\section{E. Interrelationship between karst landform evolution, human habitation, and biodiversity}

Relationship between landform evolution, human habitation, and biodiversity is depicted schematically in Figure 2. During the first stage when surface river was active, human settlement occupied open space along river courses. When the caves were exposed in the second stage, human settlement moved to the caves and distributed along dry valleys or near doline ponds. Hunting subsistence culture at this period relied on the tropical forest and big mammal existence (Elephas maximus, Elephas namadicus, Pongo pygmaeus, Hylobates syndactylus, Panthera tigris, Ursus malayanus, Rhynoceros sondaicus, Tapirus indicu, Muntiacus muntjak, Sus barbattus, Sus vittatus, Acanthion brachyurnus, Bubalus sp., Bibos sp.. Hipopotamus sp. Axis lydekkeri).

Cave habitations ended when major depression dried out provisions of extensive agricultural land. Since then, cave habitation moved to open site again. This shifting settlement was also influenced by drier environment and less big mammal population. During this period, rain forest vegetation composition was dominated by bamboos and bushes; hence the forest environment did not sustain hunting subsistence culture anymore. The subsistence transformation from hunting to agriculture was also triggered by rapid human population growth at the end of pre-historic period. Since then, megalithic culture took place.

In the modern era, the situation was inverted in which the human habitation determines geomorphologic processes. Soil erosion is accelerated due to deforestation and agricultural land extensification. This process bring about rapid sedimentation in doline ponds. Almost $90 \%$ of doline ponds is now dry. Karren in the karst hills appears to display bare land environment, while biodiversity declines drastically. Native species (Dracontomelon mangiferum, Lannea grandis, Spondias pinnata, Alstonia scholaris, Alstonia villosa, Aleurites molucana, Tamarindus indica, Calamus sp.) were replaced by exotic species commodities (Tectona grandis, Melaleucaleuca dendron, Accasia auriculiformis, Anacardium occidentale, and cassava). Big mammals mentioned above were extinct.

\section{Concluding Remark}

Gunung Sewu Karst seems to have witnessed dynamic interrelationship between landform development and human habitation history. Human habitation stages unveiled by previous archaeological works are likely governed by uplift history and landform development stages of the area. Further researches are still needed to elaborate the exact time and chronology of the stages, especially how to coupling physical environment and human history engage in mutual evolution. 


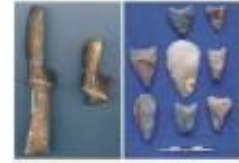

Hoon and stone tonls of cave
habitation (From PTKA)

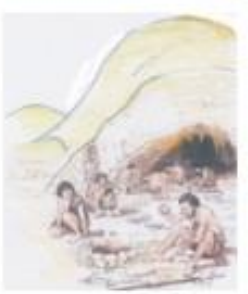

Cave Habitation

Cave habitation commenced when caves were exposed due deep incision valleys. The habitation relaid on forest (hunting and collecting culture). However during last glacial extreme in the Late Pleistocene-Early Holocene, rain forest vegetation composition dominated by bamboos and bushes. Drier environment and less bio-diversity therefore forced cave dweller to shift from hunting to agriculture.
Human habitation was along surface river sides. Hunting subsistence culture at this period relaid on the tropical forest and big mamal existence (Elephas maximus, Elephas namadicus, Pongo pygmaeus, Hylobates syndactylus, Panthera tigris, Ursus malayanus, Rhynoceros sondaicus, Tapirus indicu, Muntiacus muntjak, Sus barbattus, Sus vittatus, Acanthion brachyurnus, Bubalus sp., Bibos sp.. Hipopotamus sp. Axis bydekkeri

o p n site Habitation
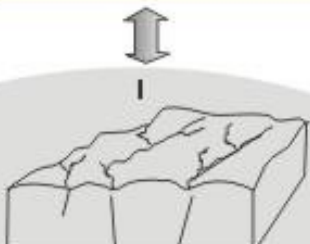

Late Pliocene-Early Pleistocene

During the first uplift, carbonate of Wonosari Fm were slightly emerge to the surface. Karstification started, surface rivers developed and lakes were formed in
the major depression of the northern vicinity of Gunung Sewu Karst.

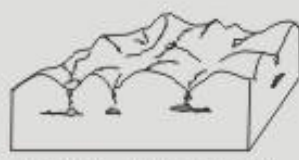

II Middle Pleistocene

In the second phase, the carbonate outcrop was uplifted and more extensive, incision along surface valley continued resulting in deep valley and cave exposure.
The drastic change took place during the third stage when Gunungsewu Karst was completely exposed reaching maximum altitude of $500 \mathrm{~m}$ from msl, most surface rivers dried out due to underground conduit development. Major lake was also drained through newly developed underground river system. Instead, pounds were scatterly formed in the bottom of dolines in which the ponor was plugged by sediment.
$R$ e c e n t Soil erosion was accelerated due to deforestation and agricultural land extensification. This process brought about rapid sedimentation in doline ponds. Almost $90 \%$ of doline ponds now dry.

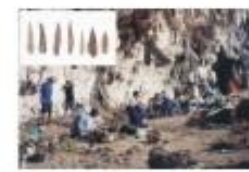

Siluation dweled tave. The insert is fools remains foun during excavation (Fror

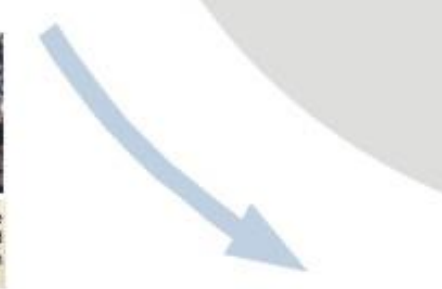

Late Pleistocene-Holocene

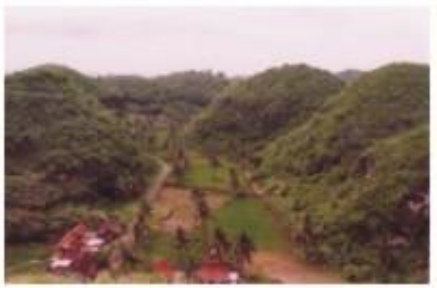

Open Site Habitation-Agriculture

Agricultural culture started when major depression and valley dried out providing extensive agricultural land. Since then, cave habitation moved to open site again. Native species were replaced by exotic species commodities (Tectona grandis. Melaleucalenca dendron, Accasia auriculiformis. Anacardium occidentale, and cassava). Big mammals mentioned above were extinct.

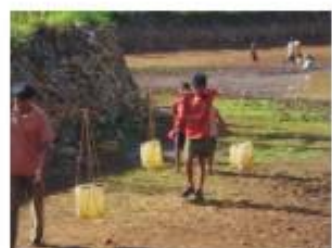

Drying doline pond caused rapid sedimentation and high evaporation

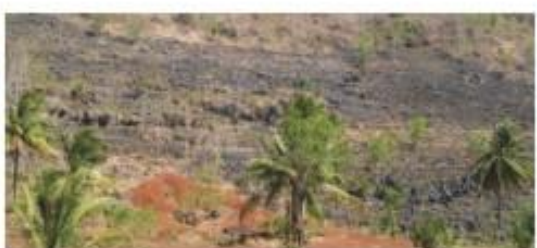

Rock disertification as a result of extensive agriculture in the karst slope hills. Accelerated erosion rate has resutled in the exposure of karen/lapies

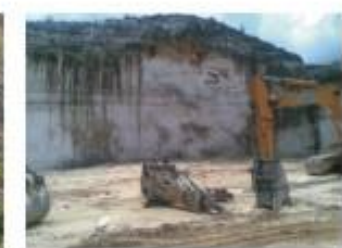

Limestone quarrying accelerates landform since the early 1980

Figure 2. Schematic diagram depicting interrelationship between karst landform evolution, human habitation, and biodiversity 


\section{Acknowledgment}

This article is part of Ph.D. research by Eko Haryono entitled Karst Development Model with special emphasis on karst valley network morphometry and Hibah Pascasarjana Research by Sutikno and Daud Tanudirdjo entitled Kajian Geoarkeologi Kawasan Gunungsewu sebagai Dasar Pengembangan Model Pelestarian Lingkungan Karst.

\section{References}

Anonymous, 2001, Rencana Detil Tata Ruang Kawasan Karst Kabupaten Gunungkidul, Kerjasama BAPPEDA Kab. Gunungkidul dan Fakultas Geografi UGM, Yogykarta.

Anonymous, 2003, Rencana Detil Tata Ruang Kawasan Karst Kabupaten Wonogiri, Kerjasama BAPPEDA Kab. Wonogiri dan Fakultas Geografi UGM, Yogykarta.

Asikin, S., Handoyo A., Pratistho B., Gafur S., 1992, Peta Geologi Lembar Banyumas, Jawa, Pusat Penelitian dan Pengembangan Geologi, Bandung.

Balazs, D, 1968, Karst Regions in Indonesia: Karszt-Es Barlangkutatas, Volume V. Budapest.

Bemmelen, RW, 1970, The Geology of Indonesia, Volume 1A, General Geology: The Hague, Martinus Nijhoff.

Haryono, E, 2000, Some properties of epikarst drainage system in Gunung Kidul Regency, Yogyakarta Special Province, Indonesia, The Indonesian Journal of Geography, 32(79-80), 75-86.

Haryono, E and Day M, 2004, Landform differentiation within the Gunung Kidul Kegelkarst, Java-Indonesia, Journal of Cave and Karst Studies, 66 (2), 56-63.

Haryono, E., 2008, Model Perkembangan Karst berdasarkan Mormometri Jaringan Lembah, Diserstasi, Universitas Gadjah Mada, Yogyakarta.

Pannekoek AJ,1949, Outline of The Geomorphology of Java, Leiden.

Matala Biogama, 2002, Penelitian Flora dan Fauna di Kawasan Karst Kabupaten Wonogiri, not Published, Fakultas Biologi UGM, Yogyakarta.

Noerdjito, 2000, Walet Gua, Makalah Diklat Perwaletan Terpadu bagi Nalapraja Aparatur Pemerintah Daerah Propinsi dan Kabupaten/Kota, Yayasan Sahabat Walet LIPIDirjen Pengembangan Daerah.

Samodra, H., Wiryosujono S., 1993, Stratigraphy and Tectonic History of the Eastern Southern Mountains, Java, Indonesia, Jurnal Geologi dan Sumberdaya Mineral, III, 14-22.

Simanjutak, T., 2002, Gunungsewu in Prehistoric Times, Gadjah Mada University Press, Yogyakarta.

Surono, BT, Sudarno I and Wiryosujono S, 1992, Geology of the Surakarta-Giritontro Quadrangles, Java, scale 1:100,000, Geological Research and Development Center, Bandung.

Sutikno, Tanudirdjo D., 2007, Kajian Geoarkeologi untuk Pengembangan Model Konservasi Kawasan Karst Gunungsewu, Laporan Penelitian Hibah Pasca Sarjana, UGM, Yogyakarta.

Urushibara-Yoshino K and Yoshino M, 1997, Palaeoenvironmental change in Java Island and its surrounding areas: Journal of Quaternary Science, 12(5), 435-442.

Waltham AC, Smart PL, Friederich, H, Eavis, A.J \& Atkinson TC, 1983, The caves of Gunung Sewu, Java:, Cave Science, 10(2), 55-96. 
Yuwono SE, 2004, Mozaik purba gunung sewu: hipotesis hasil eksplorasi gua-gua arkeologis di Kecamatan Tanjungsari - Gunungkidul, Arthropoda gua karst gunung sewu : sebuah tinjauan, Gunung Sewu: Indonesian Cave and Karst Journal, I(1), 40-51. 